\title{
Impact of Transplanting on Productivity and Profitability of Indian Mustard: A Pilot Study
}

\author{
Saroj Kumari, Har Vir Singh, R. S. Jat, G. L. Yadav*, \\ M. L. Dotaniya and R. L. Choudhary \\ ICAR-Directorate of Rapeseed Mustard Research, Bharatpur, Rajasthan, India \\ Mahatma Jyoti Rao Phoole University, Jaipur, India \\ *Corresponding author
}

\section{A B S T R A C T}

\begin{tabular}{|l|}
\hline Ke y w or d s \\
$\begin{array}{l}\text { Date of } \\
\text { transplanting, } \\
\text { Indian mustard, } \\
\text { productivity, } \\
\text { profitability }\end{array}$ \\
\hline Article Info \\
\hline $\begin{array}{l}\text { Accepted: } \\
18 \text { August } 2019 \\
\text { Available Online: } \\
\text { 10 September } 2019\end{array}$ \\
\hline \hline
\end{tabular}

The present investigation was carried out during rabi season of 2016-17 at ICARDirectorate of Rapeseed-Mustard Research, Bharatpur, Rajasthan to evaluate the effect of different stage of transplanting on growth, yield attributes, seed yield and economics of Indian mustard. The experiment was laid out in randomized block design with seven replications and three transplanting dates, viz.,13 October $\left(\mathrm{D}_{1}\right), 22$ October $\left(D_{2}\right)$ and 01 November $\left(D_{3}\right)$.The maximum values of plant height $(197 \mathrm{~cm})$, leaf area index (5.87) and SPAD-chlorophyll content (54.8) were recorded at 13 October date of transplanting $\left(D_{1}\right)$ compared to other transplanting dates. Yield attributes and seed yields were significantly affected by the date of transplanting. Results showed that length of silique $(6.23 \mathrm{~cm})$, number of seeds/silique (22.2), test weight $(7.91 \mathrm{~g})$ were also recorded highest at 13 October date of transplanting. Oil content $(41.65 \%)$ was also more in $\mathrm{D}_{1}$ followed by $\mathrm{D}_{2}$ and $\mathrm{D}_{3}$. The higher $\mathrm{B}: \mathrm{C}$ ratio was calculated in $\mathrm{D}_{1}(3.95)$ followed by $\mathrm{D}_{2}$ and $\mathrm{D}_{3}$. In nutshell, transplanting of mustard (variety, RH 406) at 13 October improved the productivity and profitability of Indian mustard. This also could open the new avenues for early establishment of crop where sowing of mustard is get delayed due to late harvesting of kharif crops.

\section{Introduction}

Rapeseed-mustard is the third most important edible oilseed crop after soybean and groundnut in India. It is one of the major sources of dietary oil in India. Indian mustard (Brassica juncea L.) is a winter season oilseed crop which thrives best in light to heavy loam soil in areas having 25-40 cm rainfall. Among the several reasons responsible for low productivity, non-adoption of good agronomic practices mostly the sowing window is the major one. The plant population and date of sowing much affected the yield and yield attributes. Very often farmers have to sown the crop late due to delayed monsoon rain, and late harvesting of Kharif crops resulting in poor crop yield. Delay in sowing might reduce yield due to its depressing effect on the plant growth, flowering duration, seed formation and productivity (Bali et al., 2000). Kumari et al.,(2012) reported late sown mustard duration 
is less due to the high temperature during the reproductive phase with concomitant reduction in yield. In general, it was observed that the mustard crop sown after October $30^{\text {th }}$ resulted in lower yields due to genetic potential limitation (Panda et al., 2004).

Indian mustard is playing a major role in oilseed production and satisfying most of the oil requirement of Indian consumers. However, late sowing of mustard cultivars was resulted in yield losses and thus affected the supply chain of oil in the market. Therefore, early crop establishment through transplanting technique could be a better alternative to minimize the yield losses in mustard. The main objective of the study was to quantify the effect of transplanting on the performance of the mustard. Accordingly, the present investigation was undertaken to assess the impact of different transplanting dates on the productivity and profitability of the Indian mustard

\section{Materials and Methods}

\section{Experimental site and Climate characteristics}

The experiment was conducted during 201617 at research farm, ICAR-Directorate of Rapeseed-Mustard Research, Bharatpur located at $77^{\circ} 30^{\prime} \mathrm{E}$ longitude, $27^{\circ} 15^{\prime} \mathrm{N}$ latitude and at an altitude of 178.37 meter above mean sea level. The climate of this zone is typically semi-arid, characterized with wide range of temperature between summer and winter. The mean weekly maximum and minimum temperature during the crop growing season fluctuated between 18.3 to $40.9^{\circ} \mathrm{C}$ and 3.5 to $22.1^{\circ} \mathrm{C}$, respectively. The mean daily evaporation from USWB class a pan evaporimeter ranged from 1.0 to $9.7 \mathrm{~mm}$ per day. The average relative humidity was fluctuated between 20.4 to $57.8 \%$ (observation taken at noon). The bright sunshine hours varied from 5.9 in January to 9.3 in April. Rainfall received during crop season was $55.8 \mathrm{~mm}$.

\section{Soil characteristics}

The soil samples were collected from surface soil $(0-15 \mathrm{~cm})$ and analyzed for soil physicochemical properties with the help of standard methods (Singh et al., 2005). The experimental site was silty clay loam in texture $(19.2 \%$ sand, $51.3 \%$ silt and $29.4 \%$ clay), $\mathrm{pH}$ (1:2 soil water suspension) 8.3 , bulk density $1.52 \mathrm{~g} \mathrm{~cm}^{3}$, field capacity (by weight) $12.5 \%$ and permanent wilting point was observed at $2.35 \%$. Soil organic C, available $\mathrm{N}$, available $\mathrm{P}$ and available $\mathrm{K}$ were measured $0.24 \%, 126.3 \mathrm{~kg} / \mathrm{ha}, 17.23 \mathrm{~kg} / \mathrm{ha}, 149.3 \mathrm{~kg} / \mathrm{ha}$, respectively. The detail of the soil physicochemical properties is presented in Table 1 .

\section{Treatment details and preparation of field}

The experiment consisted of three transplanting dates viz., 13 October $\left(\mathrm{D}_{1}\right), 22$ October $\left(D_{2}\right)$ and 01 November $\left(D_{3}\right)$. The mustard cultivar RH 406 was used as a test crop. The nursery of RH 406 variety was raised in transplanting trays before 8-10 days of date of transplanting. The 2-3 leaves stage plants were transplanted in to field in the evening hours. After transplanting a light irrigation was given to get established the plants. A buffer nursery was prepared for gap filling of the same cultivar. Gap filling was taken up after 8 days of transplanting. To eliminate weeds in experimental field, one hoeing was done at 25 days after sowing (DAS).The crop was raised as per the recommended package and practices. The crop was harvested at $80 \%$ silique turned down yellowish brown. Thereafter, plants from each net plot area $(6 \mathrm{~m} \times 6 \mathrm{~m})$ were harvested carefully and seed yield from each plot was recorded.

Observation recorded 
The observations on growth parameters were recorded at 45 days after transplanting (DAT), 60 DAT and 90 DAT. The chlorophyll content was measured with SPAD chlorophyll meter reading (SCMR) after 45 and 90 DAT. At harvesting length of tagged plants (five silique/plant) was measured with a scale and expressed as mean length of silique $(\mathrm{cm})$. The seeds of ten selected silique from respective branches were threshed, counted and average number was reported. While reporting the average number of seeds per silique, the number of seeds per silique of respective branches has been averaged. The thousand seeds were taken for recording test weight. The total biomass harvested from each plot was threshed and cleaned. The seeds so obtained were weighed and then converted in to $\mathrm{q} / \mathrm{ha}$. Harvest index was calculated by using the following formula:

Harvest index $(\%)=\frac{\text { Economic yield }(\mathrm{q} / \mathrm{ha})}{\text { Biological yield }(\mathrm{q} / \mathrm{ha})} \times 100$

Where,

Economic yield $=$ seed yield $(\mathrm{q} / \mathrm{ha})$

Biological yield $=$ seed yield + stover yield (q/ha)

The economic analysis of the treatments is very important factor to assess the practical utility of treatment for farmer's point of view. Therefore, economics of different treatments were worked out in terms of cost of cultivation, gross monetary returns (GMR), net monetary returns (NMR), and benefit-cost ratio (B:C) on per hectare area basis to ascertain the economic viability of the treatments. These economic parameters were calculated based on the prevailing market prices of different inputs and outputs.

The data obtained on various observations were tabulated and analyzed in randomized block design with seven replications by using the techniques of the analysis of variance (ANOVA) as suggested by Panse and Sukhatme (1967) and the treatment was tested by $\mathrm{F}$ test shown their significance where critical difference (CD) at 5\% level of significance was determined for each character to compared the differences among treatment means.

\section{Results and Discussion}

\section{Growth parameters}

It is evident from the data that plant height increased with the advancement of the plant growth in all three transplanting dates (Table 2 ). The October $13^{\text {th }}$ transplanting date exhibited significantly $(\mathrm{p}=0.05)$ higher plant height $(197 \mathrm{~cm})$ at all growth stages followed by October $22^{\text {th }}$ transplanting in all growth stages of plant. Similar types of observations were recorded by Afrozet al., (2011). A critically examination of data revealed that the early transplanting of mustard on $13^{\text {th }}$ October had highest plant leaves which was at par with October $22^{\text {nd }}$ at 90 DAT. Similar findings also reported by Kumar et al.,(2008).

The data revealed that early mustard transplanting on $13^{\text {th }}$ October resulted in significantly higher numbers of primary and secondary branches at 90 DAT, though it was at par with 22 October date of transplanting (Table 3). At 60 DAT, plant girth was recorded the maximum with $13^{\text {th }}$ October date of transplanting which was significantly higher over other dates of transplanting. Similar findings also reported by Kumar et al.,(2008).

Chlorophyll content in mustard leaves was significantly influenced by the different dates of transplanting (Table 4). Delayed transplanting of mustard crop significantly decreased the chlorophyll content. Early 
transplanting (13th October) of mustard recorded significantly higher chlorophyll content (54.8), which was higher over 20th October and 1st November transplanted crop. Similar findings also reported by Singh et al., 2019.

It is apparent from the data reveals that leaf area index was significantly affected by different transplanting dates at different stages (Table 4). Among different transplanting dates, the crop transplanted on October 13 produced highest leaf area index followed by $22^{\text {th }}$ October and November $1^{\text {st }}$ at all the growth stages. Similar results were also reported by Kumar et al., 1997.

The yield attributes of the mustard viz., siliqua/plant, siliqua length, seeds/siliqua, 1000-seed weight and oil content were significantly influenced by different dates of transplanting (Table 5). It is evident from data that the number of siliquae per plant was drastically reduced with delayed planting. Planting of mustard on 13th October produced significantly higher number of siliquae per plant (514) as compared to delayed planting $\left(22^{\text {nd }}\right.$ October and $1^{\text {st }}$ November). Similarly, length of siliquae was recorded significantly higher with 13th October planted crop as compared to $22^{\text {nd }}$ October and $1^{\text {st }}$ November planted crop.

Further, 13th October planted crop enhanced the length of siliquae by 4 and $12 \%$ over $22^{\text {nd }}$ October and $1^{\text {st }}$ November planted crop, respectively.It is evident from data that the number of seeds/siliquaewas drastically reduced with delayed planting. Planting of mustard on 13th October produced significantly higher number of seeds/siliquae (19.18) as compared to delayed planting ( $22^{\text {nd }}$ October and $1^{\text {st }}$ November). The different dates of transplanting brought about significant effect on test weight (1000-seed weight).
Significantly higher values of test weight was recorded in October 13 transplanted crop followed by $22^{\text {nd }}$ October and $1^{\text {st }}$ November planted crop. Similar findings were also reported by Kumari et al., 2012.

Experimental data showed that the oil content of mustard was influenced by different transplanting dates (Table 5). Oil content of mustard was decreased by delayed sowing.

Transplanting of mustard on $13^{\text {th }}$ October recorded higher oil content in seed $(41.41 \%)$ than $22^{\text {nd }}$ October and $1^{\text {st }}$ Novembertransplanted crop, though difference among the treatments was non-significant.This significant decrease in oil yield was due to the combined effect lower seed yield and lesser oil content under delayed sowing, since the oil yield is product of seed yield and the oil content.

This behavior could be ascribed to improper seed development and oil synthesis in seeds under delayed sowings, owing to restricted growth of plants as stated earlier and the rise in temperature during the seed development phase.

Decrease in oil content in rapeseed with the rise in temperature was also observed by Angrej et al., (2002). They reported that delay in sowing of rapeseed- mustard from optimum period adversely affected the oil content in seed.

Data presented in Table 6 clearly indicated that seed and stover yields and harvest index of the mustard were significantly affected by different dates transplanting. The maximum seed yield (40.1 q/ha) was produced under 13th October planting which was significantly higher by 9.0 and $37.3 \%$ over 22 October and 1 November dates of transplanting, respectively. 
Table.1 Physico-chemical properties of soil at the experimental site

\begin{tabular}{|c|c|}
\hline Particulars & Values \\
\hline \multicolumn{2}{|l|}{ Mechanical composition (Bouyoucos 1962) } \\
\hline Sand $(\%)$ & 19.2 \\
\hline Silt $(\%)$ & 51.3 \\
\hline Clay $(\%)$ & 29.4 \\
\hline Texture class & Silty clay loam \\
\hline pH (1:2 soil water suspension) (Piper 1950) & 8.3 \\
\hline Bulk density $\left(\mathrm{g} / \mathrm{cm}^{3}\right)$ (Rana et al., 2014) & 1.52 \\
\hline $\begin{array}{l}\text { Field capacity (\% by weight) (Richards, } \\
1954)\end{array}$ & 12.50 \\
\hline $\begin{array}{l}\text { Permanent wilting point (\%) (Richards, } \\
\text { 1954) }\end{array}$ & 2.35 \\
\hline $\begin{array}{l}\text { Organic carbon (\%) (Walkley and Black, } \\
\text { 1934) }\end{array}$ & 0.24 \\
\hline $\begin{array}{l}\text { Available N }\left(\mathrm{kg} \mathrm{ha}^{-1}\right) \text { (Subbiah and Asija, } \\
\text { 1956) }\end{array}$ & 126.30 \\
\hline Available P $\left(\mathrm{kg} \mathrm{ha}^{-1}\right)($ Olsen et al., 1954) & 17.23 \\
\hline Available K (kg ha $\left.{ }^{-1}\right)$ (Jackson, 1973) & 149.26 \\
\hline pH (1:2 soil water suspension) (Piper, 1950) & 8.3 \\
\hline
\end{tabular}

Table.2 Plant height and plant leaves as influenced by different dates of transplanting

\begin{tabular}{|l|c|c|c|c|c|c|}
\hline Date of transplanting & \multicolumn{3}{|c|}{ Plant height (cm) } & \multicolumn{3}{c|}{ Plant leaves } \\
\hline & 45 DAT & 60 DAT & 90 DAT & 45 DAT & 60 DAT & 90 DAT \\
\hline 13 October $\left.\mathbf{( D}_{\mathbf{1}}\right)$ & 102.34 & 156 & 197 & 46.63 & 55.87 & 93.36 \\
\hline 22 October $\left.\mathbf{( D}_{\mathbf{2}}\right)$ & 82 & 141 & 184 & 30.12 & 30.64 & 89.06 \\
\hline $\mathbf{0 1}$ November $\left.\mathbf{( D}_{\mathbf{3}}\right)$ & 74 & 124 & 174 & 22.36 & 29.44 & 73.63 \\
\hline SEm \pm & 1.6 & 2.1 & 0.9 & 1.55 & 1.47 & 3.41 \\
\hline $\mathbf{C D}(\mathbf{p}=\mathbf{0 . 0 5})$ & 5.4 & 6.9 & 2.9 & 5.12 & 4.86 & 11.30 \\
\hline
\end{tabular}

Table.3 Primary, secondary branches and plant girth as influenced by dates of transplanting

\begin{tabular}{|l|c|c|c|c|c|c|c|}
\hline Date of transplanting & \multicolumn{2}{|c|}{ Primary branches } & \multicolumn{2}{|c|}{ Secondary branches } & \multicolumn{3}{c|}{ Plant girth (cm) } \\
\hline & 90 DAT & At harvest & 90 DAT & At harvest & 60 DAT & 90 DAT & At harvest \\
\hline 13 October $\left(\mathbf{D}_{\mathbf{1}}\right)$ & 11.7 & 13.8 & 25 & 33 & 8.06 & 9.49 & 9.7 \\
\hline 22 October $\left.\mathbf{( D}_{\mathbf{2}}\right)$ & 9.5 & 12.4 & 21 & 29 & 6.79 & 7.89 & 8.2 \\
\hline $\mathbf{0 1}$ November $\left.\mathbf{( D}_{\mathbf{3}}\right)$ & 8.9 & 11.2 & 19 & 26 & 5.60 & 6.37 & 7.4 \\
\hline SEm \pm & 0.51 & 0.21 & 1.06 & 1.24 & 0.33 & 1.04 & 0.47 \\
\hline $\mathbf{C D}(\mathbf{p}=\mathbf{0 . 0 5})$ & 1.697 & NS & 3.50 & NS & 1.0 & NS & NS \\
\hline
\end{tabular}


Table.4 Chlorophyll content and leaf area index as influenced by different dates of transplanting

\begin{tabular}{|l|c|c|c|c|c|}
\hline \multicolumn{1}{|c|}{ Date of transplanting } & \multicolumn{2}{|c|}{ Chlorophyll content } & \multicolumn{3}{c|}{ Leaf area index } \\
\hline & 45 DAT & 90 DAT & 45 DAT & 90DAT & At harvest \\
\hline 13 October $\left(\mathbf{D}_{\mathbf{1}}\right)$ & 45.2 & 54.8 & 3.24 & 5.87 & 3.87 \\
\hline 22 October $\left(\mathbf{D}_{\mathbf{2}}\right)$ & 41.4 & 50.3 & 3.01 & 5.29 & 3.16 \\
\hline 01 November $\left(\mathbf{D}_{\mathbf{3}}\right)$ & 37.8 & 43.7 & 2.89 & 4.76 & 2.47 \\
\hline SEm \pm & 0.68 & 0.98 & 0.35 & 0.34 & 0.29 \\
\hline CD $(\mathbf{p}=\mathbf{0 . 0 5})$ & 2.24 & 3.25 & 1.08 & 1.2 & 0.91 \\
\hline
\end{tabular}

Yield attributes

Table.5.Yield attributes as influenced by different dates of transplanting

\begin{tabular}{|l|c|c|c|c|c|}
\hline Date of transplanting & $\begin{array}{c}\text { Number of } \\
\text { silique/plant }\end{array}$ & $\begin{array}{c}\text { Length of siliqua } \\
(\mathbf{c m})\end{array}$ & $\begin{array}{c}\text { Number of } \\
\text { Seeds/silique }\end{array}$ & $\begin{array}{c}\text { Test weight } \\
(\mathbf{g})\end{array}$ & $\begin{array}{c}\text { Oil content } \\
(\boldsymbol{\%})\end{array}$ \\
\hline $\mathbf{1 3}$ October $\left(\mathbf{D}_{\mathbf{1}}\right)$ & 514 & 6.23 & 22.20 & 7.91 & 41.65 \\
\hline $\mathbf{2 2}$ October $\left(\mathbf{D}_{\mathbf{2}}\right)$ & 437 & 5.99 & 19.80 & 7.02 & 41.02 \\
\hline $\mathbf{0 1}$ November $\left(\mathbf{D}_{\mathbf{3}}\right)$ & 358 & 5.53 & 17.86 & 6.83 & 40.74 \\
\hline SEm $\mathbf{n}$ & 10.229 & 0.061 & 0.303 & 0.052 & 0.26 \\
\hline $\mathbf{C D}(\mathbf{p}=\mathbf{0 . 0 5})$ & 33.875 & 0.201 & 1.003 & 0.173 & NS \\
\hline
\end{tabular}

Seed and stover yields and harvest index

Table.6 Seed and stover yields and harvest index as influenced by different dates of transplanting

\begin{tabular}{|c|c|c|c|}
\hline Date of transplanting & Seed yield (q/ha) & Stover yield (q/ha) & Harvest index (\%) \\
\hline 13 October $\left(D_{1}\right)$ & 40.1 & 90.5 & 30.70 \\
\hline 22 October $\left(D_{2}\right)$ & 36.8 & 82.3 & 30.50 \\
\hline 01 November $\left(D_{3}\right)$ & 29.2 & 70.2 & 29.29 \\
\hline SEm \pm & 1.11 & 2.31 & 0.74 \\
\hline CD $(p=0.05)$ & 3.21 & 7.02 & NS \\
\hline
\end{tabular}

Table.7 Economic parameters as influenced by different dates of transplanting.

\begin{tabular}{|l|c|c|c|c|}
\hline Date of transplanting & $\begin{array}{c}\text { Cost of } \\
\text { cultivation }\end{array}$ & $\begin{array}{c}\text { Gross monetary } \\
\text { returns }\end{array}$ & $\begin{array}{c}\text { Net monetary } \\
\text { returns }\end{array}$ & B:C ratio \\
\cline { 2 - 5 } & & $(\mathbf{R s})$ & 104850 & 3.95 \\
\hline 13 October $\left(\mathbf{D}_{\mathbf{1}}\right)$ & 35500 & 140350 & 93300 & 3.63 \\
\hline 22 October $\left(\mathbf{D}_{\mathbf{2}}\right)$ & 35500 & 128800 & 66700 & 2.88 \\
\hline 01 November $\left(\mathbf{D}_{\mathbf{3}}\right)$ & 35500 & 102200 & & \\
\hline
\end{tabular}

Further, seed yield also recorded significantly higher with 22 October than 1 November dates of transplanting. Seed yield of crop depends on the source-sink relationship and also on the different components of source and sink. Early transplanting on 13 October produced highest seed yield might be due to larger growing period and cumulative effect of effective rainfall and favorable weather conditions which helped in better growth and development of the mustard plants and resulted into better seed yield. Delayed transplanting decreased the yield attributes and yield as these parameters were adversely influenced in the present experiment as the sowing was delayed beyond October 13 . Rapeseed and mustard when sown later of October faced with cool and even frosty nights as well as reduced sunshine hours which adversely affected photosynthesis and other 
growth as well as development processes in plants resulting in decreased seed and biological yields. Adverse effect of low temperature on flowering, siliquae setting and seed development in rapeseed and mustard have also been reported by, Adak et al., 2011, Biswas et al., 2011.

Stover yield of mustard was also decreased by delayed transplanting. Sowing of mustard on $13^{\text {th }}$ October recorded higher stover yield than $22^{\text {nd }}$ October and $1^{\text {st }}$ November transplanted crop. Mustard transplanted on October 13 resulted higher harvest index followed by $22^{\text {th }}$ October. Further also observed that November sowing caused the significant reduction in harvest index as compared to October sowing (Lalluet al., 2010, Panda et al., 2004).

\section{Economics}

Data on different economic parameters are presented in Table 7. The common cost of cultivation for mustard was Rs. 35500 per hectare. The market value of grain and straw was consideration for determination of gross monetary returns (GMR) under each treatment. The net monetary return was calculated by subtracting the cost involved into the gross monetary returns. The data reveals transplanting on $13^{\text {th }}$ October had the maximum return (Rs. 104850/ha), while the lowest return (Rs. 66700/ha) was recorded under transplanting on $1^{\text {st }}$ November. The net monetary returns (NMR) showed the similar trend as GMR. Benefit: cost ratio (B:C ratio) refers to the monetary gain over on each rupee of investment and expressed as profitability of a treatment. The $\mathrm{B}: \mathrm{C}$ ratio was found the maximum (3.95) under transplanting on $13^{\text {th }}$ October, while least $\mathrm{B}: \mathrm{C}$ ratio (2.88) was recorded on $1^{\text {st }}$ November transplanting. Thus, transplanting on $13^{\text {th }}$ October was more profitable than transplanting on $22^{\text {nd }}$ October and $01^{\text {st }}$ November. These findings are corroborated the work of Kumari et al., (2012) and Ram et al., (2008). Mustard is a one of the important oilseed crop in India. Its production is much influenced by the planting time. During the experiment maximum plant height, plant leaves, primary and secondary branches, leaf area index, chlorophyll content, length of siliquae, number of seeds/siliquae, test weight, oil content, yield and harvest index was observedmaximumat $13^{\text {th }}$ October date of transplanting compared to $22^{\text {nd }}$ October transplanting and 01 November transplanting. Net monetary return and $\mathrm{B}: \mathrm{C}$ ratio was also higher in $13^{\text {th }}$ October transplanting. This study highlighted the appropriate sowing time in mustard. In conclusion, $13^{\text {th }}$ October date of transplanting is beneficial for getting maximum yield of mustard variety RH 406in Rajasthan, India. Further, transplanting technique in mustard could open the new avenues for early establishment of crop where sowing of mustard is get delayed due to late harvesting of kharif crops.

\section{Acknowledgement}

Authors are highly thankful to staff of the Crop Production Unit, ICAR-DRMR, Bharatpur for valuable help during the course of study.

\section{References}

Adak T, Bhaskar N and Chakravarty N V K. 2011. Response of Brassica to micro environment modification under semi-arid agroecosystem. Indian Journal of Agriculture Sciences, 81 (8): 744-50.

Afroz M M, Sarkar M A, Bhuiyan M S U and Roy A K. 2011.Effect of sowing date and seed rate on yield performance of two mustard varieties. Journal of Bangladesh Agricultural University 9 (1): 5-8.

Angrej S, Dhingra K K, Jagroop S, Singh M P, Singh J and Singh A. 2002. Effect of sowing time and plant density on growth, yield and quality of Ethiopian mustard (Brassica 
carinata). Agricultural Research Journal 39(4): 471475.

Bali A S, Shah M H, Hasan B. 2000. Effect of plant density on Brown Sarson under different levels of nitrogen and phosphorus. Indian Journal of Agronomy, 45: 174-178

Biswas C, Singh R and Vijaya P K. 2011. Dynamics of white rust disease in mustard (Brassica juncea) in relation to date of sowing and weather parameters. Indian Journal of Agriculture Science81(12): 118790.

Jackson M L. 1973. Soil Chemical Aanalysis, 2nd Edition, pp 498. Prentice Hall of India Pvt Ltd, New Delhi.

Kumar R, Singh R P and Yashpal. 2008. Yield and quality of Brassica species as influenced by different dates of sowing and varieties. Pantnagar Journal of Research 6 (1): 6-11.

Kumar S, Singh J and DhingraKK. 1997.Leaf area index with solar radiationinterception and yield Indian mustard (Brassica juncea) as influenced by plant population and nitrogen. IndianJournal of Agriculture Sciences 42(2): 348-351.

Kumari A, Singh R P and Yashpal. 2012. Productivity, nutrient uptake and economics of mustard hybrid (Brassica juncea) under different planting time and row spacing. Indian Journal of Agronomy 57 (1): 61-67.

Lallu R S, Baghel V S and Srivastava S B L. 2010. Assessment of mustard genotypes for thermo tolerance at seed development stage. Indian Journal of Plant Physiology 15 (10): 36-43.

Olsen B C, Cole C V, Watenabe F S and Dean L A. 1954.Estimation of available phosphorus by extraction with sodium carbonate.USDA Circular No. 939, p 19.

Panda B B, Bandyopadhyay S K and Shivay Y S. 2004. Effect of irrigation level, sowing dates and varieties on growth, yield attributes, yield, consumptive water use and water use efficiency of Indian mustard (Brassica juncea). Indian Journal of Agriculture Science 74 (6): 331-342.

Panse V G, and Sukhatme P V. 1967. Statistical methods for Agricultural Workers, ICAR, Publication New Delhi.

Piper C S. 1950.Soil and Plant Analysis, p 2867.The University of Adelaide, Australia.

Ram P, Prasad K, Dixit V, Khan N and Sonker T C. 2008.Effect of row spacing and sulphur on growth, yield attributes, yield and economics of mustard [Brassica juncea $(\mathrm{L}$.$) Czern\&Coss].Plant Archives 8(2):$ 633-635.

Rana K S, Choudhary A K, Sepat S, Bana R S and Das A. 2014. Methodological and Analytical Agronomy, p 276.Post Graduate School, IARI, New Delhi, India.

Richards L A. 1954.Diagnosis and Improvement in Saline, Alkali Soils. Handbook No. 60, USDA, Washington.

Singh D, Chhonkar PK, Pandey RN (2005) Soil plant water analysis:a methods manual. Westville, New Delhi

Singh HV, Meena M K, Choudhary R L, Dotaniya M L, Meena M D, Jat R S, Premi O P and Rai P K. 2019. Effect of direct sowing and transplanting on yield performance of Indian mustard. International Journal of Current Microbiology and Applied Science. 8 (2): 509-515.

Subbiah B V and Asija G L. 1956.A rapid procedure for the estimation of available $\mathrm{N}$ in soils.Current Science 25(8): 259-60.

Walkley A J and Black C A. 1934. Estimation of soil organic carbon by the chronic acid titration method. Soil Science 37: 29-38.

\section{How to cite this article:}

Saroj Kumari, Har Vir Singh, R. S. Jat, G. L. Yadav, M. L. Dotaniya and Choudhary R. L. 2019. Impact of Transplanting on Productivity and Profitability of Indian Mustard: A Pilot Study. Int.J.Curr.Microbiol.App.Sci. 8(09): 1658-1665.

doi: https://doi.org/10.20546/ijcmas.2019.809.188 